can be used in the spray chamber as well as hydrant water. Bear in mind if you know the absolute bumidity and temperature of the air as it leaves the humidifier or spray chamber, the thermostat in the breeding chamber can be set so as to lower the humidity of the air as it passes through the heating chamber. Of course, this increases the temperature of the air.

Mr. W. C. O'KANE: I would like to ask Mr. Dean how in summer, when the atmosphere is saturated, he is going to maintain a low humidity in his machine.

Mr. G. A. Dean: Pass the air through cold water which will give it a temperature within one degree of the water and then condition the air in the heating chamber, by setting the thermostat in the breeding chamber so as to heat or expand the air which will reduce the humidity. If hydrant water is used I don't suppose the temperature would be much below 60 degrees. There would be no difficulty whatever in maintaining a low humidity with a high temperature.

Mr. W. C. O'Kane: With a low temperature and low humidity.

Mr. G. A. Dean: You cannot get a temperature in summer lower than the water used in the spray chamber. If a temperature lower than the hydrant water is desired you must use ice water or even salty ice water. This will give you a low temperature, say perhaps thirty degrees. Then if this air is heated, say to sixty or seventy degrees in the heating chamber, it will be expanded and, of course, the humidity will be lowered. It should be remembered that the apparatus is so constructed as to use the air from the breeding chamber, which will enter the spray chamber already partly conditioned.

President H. T. Fernald: We will now listen to a paper by Dr. Howard.

\title{
NOTES ON THE PROGRESS OF ECONOMIC ENTOMOLOGY
}

\section{By L. O. Howard}

When General W. G. LeDuc took office as United States Commissioner of Agriculture July 1, 1877, just 37 years ago, the annual appropriation to the Department was $\$ 174,086.96$, and there were 77 employees. The Department was in the main a statistical, correspondence and seed distribution bureau. Virtually no research was being carricd on. The entomologist, with one assistant only, was engaged almost entirely in the general museum work of the Department. In the country at large there were no state experiment stations, and but three state entomologists, Riley in Missouri, Thomas in Illinois, and Fitch in New York, the last past his days of work. There were prac- 
tically no teachers of entomology. Hagen had a few students at Harvard, but did not touch on the economic aspects of the science; Comstock was just beginning to teach at Cornell; Burrill was giving a few lectures out west, and Fernald was soon to begin at Orono.

When Doctor Houston took office as Secretary of Agriculture July 1, 1913, the annual appropriation to the Department was practically eighteen millions of dollars $(\$ 17,986,945)$ and there were 14,478 employees. The Department had become the greatest research organization in the world. The appropriations for entomology were $\$ 742,210$. The entomological service had become a large Bureau with about six hundred employees of whom more than two hundred were scientifically trained experts. Every state had its competent agricultural experiment station with a force of entomologists. Practically every state had also its agricultural college with teaching in general and economic entomology. In California there were even County Entomologists, and Boston and Philadelphia had their City Entomologists.

In a way the wonderful general increase in agricultural research and agricultural endeavor had carried economic entomology along with it. The passage of the Hatch act and the consequent founding of the state experiment stations were responsible at once for a great increase in the number of working entomologists, while in immediate succession the introduction of the gipsy moth into New England, the appearance of the San José scale in the cast, the march of the cotton boll weevil into the southern states, and the discovery of the carriage of disease to man and animals by insects, have made the importance of entomological work greater and greater. It is no wonder that the country rose to these emergencies; that Congress and the legislatures have given large appropriations, and that by virtue of the successful investigations of our rapidly increasing group of entomological workers, the United States has already gained a commanding position among the nations of the world in this branch of applied science.

It is not generally realized, except among a limited group of teachers, just how this extraordinary advance in a few years has influenced the number of students seeking information on economic entomology at the different institutions, nor just in what way it has influenced the character of the instruction. The present year in six of the leading agricultural colleges where most attention is paid to economic entomology, there are 1531 students in entomology and 51 teachers of entomology. These institutions are the Ohio State University, the University of California, Cornell University, the Massachusetts Agricultural College, the University of Illinois and the University of Nebraska. These six I have chosen bccause they have the largest number of students in this line, but in every agricultural college in the 
country sound teaching is going on. In the south, at Clemson College, S. C., at Auburn, Ala., at Baton Rouge, La., and at College Station, Texas, and elsewhere, there are numbers of students and excellent courses. In the northwest it is the same. At Wisconsin there are 103 students and five teachers. In the small college at Bozeman, Montana, there are 27 students. The men in charge of these different departments are all practical men. Most of them, in fact I think all of them, are primarily economic workers. Many of them have been and are still connected with the state agricultural experiment stations. Some of them have been connected with the force of the Bureau of Entomology of the United States Department of Agriculture. Several of them are still collaborators of the Bureau. It follows that these men know the economic problems which confront us, and that they have a broad knowledge of what is going on, not only in this country but in other countries; and it follows further that the instruction which they give is that best designed to bring practical results. Moreover they are a harmonious and coöperative body of men. They all belong to the Association of Economic Entomologists, which, through its annual meetings and its standing committees is constantly facilitating such coöperation. All of these men are keen to grasp new ideas and are so non-conservative as to methods of teaching that they will at any moment introduce new features and new methods.

In its international aspects, economic entomology is developing with great rapidity and will continue to do so. The Association of Economic Entomologists early elected to its membership practically all of the official entomologists of foreign countries, which brought about a universal exchange of publications and frequent correspondence. This has led to visits to America by many foreign entomologists, and many of our own men have gone abroad, so that personal relationship has brought about friendships and mutual aid. There are constant visits to this country on the part of younger men from other countries, for study in the different lines of economic entomology, and the Imperial Bureau of Entomology of Great Britain has, with Dr. Andrew Carnegie's financial aid, founded a series of scholarships in economic entomology which brings several specially selected young Englishmen to this country each year to study in the Bureau and at the colleges and experiment stations. There are six of them in the United States at the present time. They all want to go back to take part in the war, but their government will not let them do so. All this will bring about in the near future an increase in the solidarity of interests and information and mutual helpfulness which already exists among the economic entomologists of the whole civilized world. Each new idea is and will be almost instantly known to all and speedily tested in 
every climate and under all sorts of world conditions. Important parasites found in a remote region will not have to be carried immense distances in the future, but will be relayed from one coyntry to another, a generation or so reared at each stop and then sent on.

The passage of the Federal Horticultural Law in 1912 has brought us into the closest relationship with the plant inspection services of other countries, and last year at a congress in Rome an effort was made to harmonize laws and to bring about comparatively uniform systems by the different countries. This is a movement which will gain force in the future. One of the more trivial and unconsidered aspects of the present war is its effect on inspection services. Of course shipments of plants and plant products from the countries engaged are almost entirely at a standstill, but arrangements have been made by our authorities to accept Holland's certificates for Belgian shipments, and the other day I received a note from the French Ambassador stating that his government had cabled him on behalf of Dr. Paul Marchal to the effect that the French inspection service will be carried on to the best of his ability under the circumstances.

How the entomological problems of the future will be met can only be guessed at, but the work of the past fow years has greatly increased our belief in the necessity for the most thorough biological study of evcry injurious form. So many instances have occurred with species whose life history was apparently well understood and whose behavior was also thought to be known but which have been found under intensive study to possess unexpected points of attack, that the importance of the closest study of every species from every point of view has become very evident. The trend is towards intensive study of every phase of the insect's existence.

Since we have built up in this country in these past twenty or thirty years such a very respectable branch of knowledge which we have termed "economic entomology" or "applicd entomology," we are naturally proud of our accomplishment and anxious to sce the good work continue in the same general way and under the same name. But there is a tendency now to break into the solidarity of our branch of science and to unite us with the plant-disease people under the term "phytopathology" in so far as insects affect plant life, and with the internal parasite people, under the term "parasitology," where insects directly affect man or animals. I think that economic entomologists should resist this tendency. The term "phytopathology," in this significance, apparently originated in Germany. Perhaps for the reason that at the time there were practically no economic entomologists in Germany, there was no protest, but when the European San José scale scare occurred in 1898 and an inspection service was started in that 
country to prevent the incoming of this dreaded insect, a plant disease man was put at the head of the service, a curious anomaly which probably might not have occurred elsewhere. It is true that an entomologist was appointed under this person, but the service suffered. The term "phytopathology" should be restricted to plant diseases, and many Germans themselves believe this. A society of economic entomologists, on the plan of our own association, was founded in Germany last year, and, through its efforts and increasing importance, it is likely that the encroaching botanists will be held in check. It is perhaps of sufficient interest to state that the congress which was called at Rome last year to consider inspection services was called a phytopathological congress although it was distinctly understood that the function of the congress was to consider questions relating principally to the prevention of international transportation of injurious insects. The United States sent no delegate to this convention, but did send a letter urging that futurc congresses of the same nature should be termed congresses of economic entomology and phytopathology.

It is very obvious that plant pathology and economic entomology are unrelated in their basic principles. Their successful study requires from workers absolutely different training and wholly different technique. To combine them into one service would be impracticable, except as units of a large agricultural institution. To combine them under one name as a branch of agricultural science is absurd!

The second term, "parasitology," has perhaps a better justification than the other, but the questions relating to the damage done by insects to man and domestic animals is competently handled by the economic entomologists familiar with the whole range of entomological activity. Why take a protozoölogist or a helminthologist and make him learn all about the insects that affect animals in order to become a parasitologist, when the men who have always worked at economic entomology are handling the same questions under another term? In our entomological proceedings and in our entomological journals and our entomological reports all matters relating to insects are brought together. Why put entomological material together with a lot of plant disease material into a publication entitled phytopathology, and why mix up a lot of entomological material with a lot of other material on worms and the like in a publication called parasitology? And after a branch of applied science has been so well grounded and so successfully carried on under a comprehensive and at the same time exact term like "economic entomology," why try to confuse matters and break into a field so well defined and so successfully organized? Both terms have come to us from Europe, and the attempt to in- 
troduce them into this country has been made by Americans who have studied under European masters. It seems to me, however, that the term "economic entomology," or "applied entomology," is more likely to take a firmer hold in Europe than is the term "phytopathology," in this significance, to gain ground in this country, and that will mean that internationally the term "economic entomology" as applying to the whole field will be generally adopted.

That side of economic entomology which relates to the carriage of disease by insects has been aptly termed "medical entomology," and is best carried on by trained entomologists. The truth of this statement is probably self-evident, but if a convincing argument is needed, it will be found in Hunter's admirable address on medical entomology before the Twenty-fifth Annual Meeting of the Association of Economic Entomologists (Journal of Economic Entomology, February, 1913 , pages 27 to 38 ). It is in this field of applied entomology that we must perhaps look for the greatest advances in coming years.

And now at the close of 1914, after considering the results already achieved, and with a knowledge of the investigations under way and of the men who are handling them, with the sound instruction which is being given in two score institutions of learning, with the hundreds upon hundreds of clever students, many of whom will make this field their life work, it is impossible to avoid the conclusion that we are carrying on and will continue to carry on a winning fight against the greatest enemies of the human race.

Mr. C. Gordon Hewitr: I would like to express my great appreciation and full concurrence with all that Dr. Howard has said in this most admirable brief résumé of the present position of economic entomology. I want to say for my own part that I am entirely in sympathy with the remarks of Dr. Howard in the latter part of his address where he spoke of merging economic entomology and plant pathology under one head. Dr. Howard has pointed out that the misuse of the term originated in Europe. For many years there were not in Europe economic entomologists of the same training and standard as we have here and often the plant pathologist and economic entomologist were one and the same person and the work was included under the same head, particularly on the European continent. I am very glad, indeed, that Dr. Howard has pointed out the importance of keeping entomological work separate, because I think we ought to take a firm stand at this time when there is still a tendency in certain quarters to include entomology under the term phytopathology. While we all realize that our work is very intimately associated with plant 
pathology, just as it is also with bacteriology, it is nevertheless necessary to keep it absolutely distinct.

Before sitting down, I should like to publicly express my hearty thanks to Dr. Howard and to the members of the Bureau and also to entomologists in the United States-for their hearty coöperation with us in our work in Canada. I realize more than anyone else the necessity of our work being international in scope and character. The international boundary is not recognized by our governments in a military manner and as insects do not recognize such political frontiers, we shall succeed best in our efforts by the closest coöperation over the whole range covered by the insects we may be endeavoring to control.

Mr. F. P. FelT: It is unnecessary to discuss Dr. Howard's paper, because he has given us a most admirable summary; but I think, speaking for myself and probably for other members of the Association, that we all heartily indorse Dr. Howard's position.

President H. T. Fernald: I have been very much interested in Dr. Howard's remarks and heartily agree with him on every point which he has made-in fact, the paper was so conclusive that I questioned in my own mind if there would be the possibility of much discussion on lines where we were all certainly so much in hearty agreement with the positions he took.

\section{Report of the Section of Apiary Inspection}

The third annual meeting of the Section of Apiary Inspection was held in Philadelphia, Monday evening, December 28, 1914. Inspec-. tors were present from ten different states. Reports of progress being made in apiary inspection work were given by all inspectors present. It was reported that efforts are now being made by several states to have a new apiary inspection law passed. Two states reported failure on the part of their legislators to make appropriation for apiary inspection but stated that the mistake would probably result in larger appropriations at the next session. Reports from other states indicate increasing appropriations for this kind of work.

Dr. E. F. Phillips reported that he had on hand an unexpended balance of $\$ 14.25$, left from membership dues received from members of the Association of Official Apiary Inspectors of the United States and Canada which was organized December, 1911, at Washington. After this association affiliated with the Association of Economic Entomologists as the Section of Apiary Inspection, it was impossible for eleven of these members to become members of the section because they were not entomologists. Dr. Phillips proposed that membership dues be returned to these eleven men and that the balance of $\$ 3.25$ 